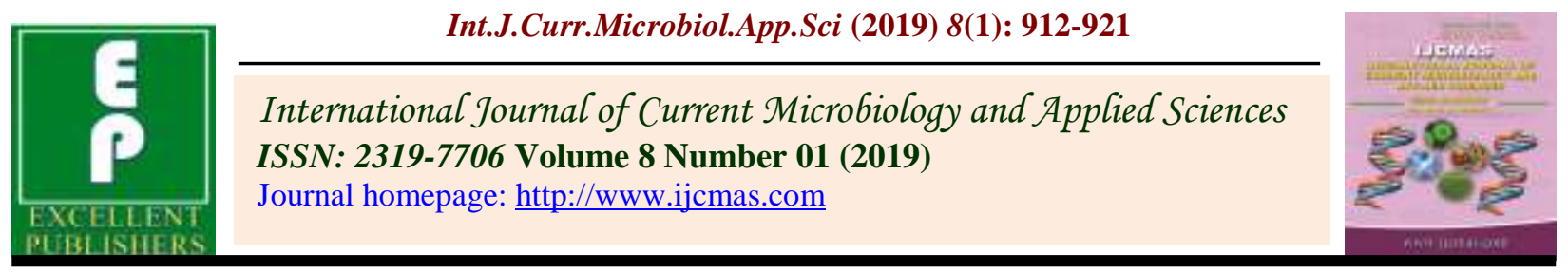

Original Research Article

https://doi.org/10.20546/ijcmas.2019.801.099

\title{
Managing Black Rot Disease of Cabbage by Use of Tolerant Varieties within Kisii County- Kenya
}

\author{
Jackson Ombuna Gitange*, Johnson Nyangeri and Samson Maobe
}

Faculty of Pure and Applied Sciences, Kisii University, 408-40200, Kisii-Kenya

*Corresponding author

\section{A B S T R A C T}

\begin{tabular}{|l|}
\hline Ke y w o r d s \\
Xanthomonas \\
campestris, \\
Copenhagen \\
market, Gloria F1 \\
Hybrid, \\
Susceptibility, \\
Disease score \\
\hline Article Info \\
\hline $\begin{array}{l}\text { Accepted: } \\
\text { 07 December } 2018 \\
\text { Available Online: } \\
\text { 10 January } 2019\end{array}$ \\
\hline
\end{tabular}

In this research, two common varieties of cabbage grown in Kisii County were selected and used to evaluate and identify the availability of cabbage germplasm resistant to black rot disease. The two varieties used were Copenhagen market variety labeled as $\mathrm{V}_{1}$ and Gloria F1 Hybrid variety labelled as $\mathrm{V}_{2}$. Seeds from the two varieties were both inoculated with $10^{4} \mathrm{CFU} / \mathrm{ml}$ suspensions of Xanthomonas campestris $p v$. Campestris field bacterial isolates before establishing the seeds in separate Greenhouse nursery beds. The seedlings were then transplanted in to the field using a Randomized Block Design with experimental plots measuring $4 \mathrm{~m}$ by $3 \mathrm{~m}$. Disease severity was scored on a scale of 1-9 as the plants were growing in the field, in all the four replicas and in both seasons 1 and 2. The data obtained was statistically computed by Statistical analysis system (SAS) using Analysis of Variance (ANOVA). Mean scores were compared using mean separation procedures by Least Significance Difference (LSD) and the Tukey's multiple range test and all tests of significance were conducted at $\mathrm{P} \leq 0.05$. The research findings obtained indicates that there was significant difference between the disease scores for variety 1 and variety 2 in both seasons 1 and 2, and across the seasons. In summary, variety 2 had significantly $(\mathrm{p}<0.05)$ lower score (2.733) compared to variety 1 (3.506) and was therefore, considered as being more tolerant to black rot disease.

\section{Introduction}

Cabbage (Brassica oleracea var. capitata L.) is considered as one of the most important vegetable that is widely grown. Scientifically, it belongs to the family of Brassicaceae, formerly known as Cruciferae family (Hall et al., 2002; Arthur, 2012). The crop draws its importance from its nutritional, health, commercial and industrial benefits (Zhao et al., 2005; Bong et al., 2012; Kim et al., 2013; Lee et al., 2015).Commercially, the production of the crop has earned income to many smallholder families in Kisii, and especially the youth and women who are largely unemployed. The crop is also grown for its industrial production of vegetable oil (Zhao et al., 2005; Bong et al., 2012; Lee et al., 2015). Nutritionally, white cabbage is a good source of fibre in the diet that forms an ingredient in condiments and spices. It contains a high amount of vitamins and minerals such as vitamins A, B6, C, K, folic acids, proteins and minerals such as calcium. 
In terms of health, the crop has anticarcinogenic properties and thus reduces the risk of some forms of cancer such as colorectal cancers (Fahey et al., 2001; Alana et al., 2008; Preedy et al., 2011). It is also a good meal for people with diabetes due to its low calorific content (Mike, 2009; Preedy et al., 2011).

Despite all these benefits, the production of this crop in Kisii County is still wanting due to several challenges which include pests and disease destruction. Black rot disease is caused by a bacterium called Xanthomonas campestris $p v$. campestris (Pammel) Dowson and is considered as most destructive disease of cabbage (Alvarez, 2000; Vicente and Holub, 2013; Lema et al., 2012). The disease causes losses amounting to over $50 \%$ to total crop loss in warm and wet seasons (Lo and Wang, 2001; Varela et al., 2003; Williams, 2007; Bila, 2008; Singh et al., 2011; Otipa et al., 2013).

Many techniques have been employed to control the disease but it has proven difficult to manage due to its seed-borne nature and the modes through which it is spread. The bacterium Xanthomonas campestris $p v$. campestris habituates crop residues, cruciferous weeds and ornamentals from where it is spread to the main crop through rain splashes, surface run off, wind, Farm machineries, irrigation water, insect contamination and farm workers as they move from one field to another (Vicente et al., 2001; Lema et al., 2011).

The bacterium spread through the vascular tissues, clogging the transport vessels and thus leading to formation of $\mathrm{V}$-shaped necrotic lesions, developing inwards from the leaf margin (Alvarez, 2000; Singh et al., 2011). Chemical control is being discouraged due to its negative effects to the environment and its low efficacies (Bila et al., 2013; Massomo et $a l ., 2003)$. Use of resistant germplasm is being considered as one of the best practices for managing the disease and is therefore, being prioritized by many breeders developing resistant varieties to black rot disease. However, there is very little knowledge on the availability of cabbage genomes resistant to black rot disease as most locally available varieties of cabbage are highly susceptible (Massomo, 2002; Massomo et al., 2003). Therefore, the main objective of this research study is to evaluate and identify black rot disease resistant germplasm among the common cabbage varieties grown in Kisii County for recommendation to the farmers.

\section{Materials and Methods}

In this research, two common varieties of cabbage grown in Kisii County were identified, selected and used to establish their level of resistance to black rot disease. The two varieties are Copenhagen market variety labeled as $\mathrm{V}_{1}$ and Gloria $\mathrm{F} 1$ Hybrid variety labelled as $\mathrm{V}_{2}$. The methodology used to achieve this objective has been discussed under the following sub-headings; Isolation and identification of Xanthomonas campestris $p v$. Campestris, inoculation of seeds, land preparation, Nursery and field establishment of the seedlings, data collection and analysis.

\section{Isolation and identification of Xanthomonas campestris pv. Campestris}

The cabbage leaves obtained from the field were washed in running tap water and airdried at room temperature $\left(27{ }^{0} \mathrm{C}\right)$. The dried leaves were placed in 1\% tween-20 solution to wet them. The leaves were then place in $10 \%$ Sodium hypochlorite solution for 5 minutes to disinfect them after which they were rinsed 5 times using sterile distilled water and then airdried on a clean disinfected bench. Leaf segments measuring $3 \mathrm{~mm} \times 4 \mathrm{~mm}$ were cut off from the lesion margins of the dried and 
sterilized leaves. The leaf segments were then placed in a $50 \mathrm{ml}$ beaker containing $0.85 \%$ sterile saline $(\mathrm{NaCl})$ solution and left to stand for 15 minutes in a lamina air-flow chamber to allow the bacteria to ooze out of the plant tissue into the saline solution. The leaf tissue segments were then removed.

Loopfuls of the saline solution were streaked on pre-chilled plates (at $-2^{0} \mathrm{C}$ to $-4^{0} \mathrm{C}$ ) containing Nutrient Agar. $10 \mathrm{mg} / \mathrm{ml}$ of nitrofurantoin and $0.5 \mathrm{mg} / \mathrm{ml}$ vancomycin were added to the nutrient agar medium to prevent the growth of saprophytic and antagonistic bacteria respectively. Saprophytic and antagonistic bacteria associated with crucifer tissues grow at a faster rate and thus prevent the growth of Xanthomonas campestris $p v$. campestris. The plates were then incubated for 48 hours at $28{ }^{0} \mathrm{C}$ after which they were inspected for the presence of pale yellowish and convex mucoid bacterial colonies.

Sub-culturing of the colonies was done on yeast dextrose Calcium carbonate (YDC) agar to purify bacterial colonies. The purified colonies were then stored at $-80{ }^{0} \mathrm{C}$ on porcelain beads in Protect tubes maintained on nutrient agar at $25{ }^{0} \mathrm{C}$.

Cultural and staining characteristics associated with Xanthomonas campestris pv. Campestris, together with pathogenicity tests were used to identify the bacterium Xanthomonas campestris pv. campestris. Pathogenicity tests were carried out in accordance with Vicente $e t$ al., (2001) and Miller et al., (2005) International Seed Testing Association (ISTA), standard procedures. This was achieved through foliar spraying of 4 weeks old seedlings of cabbage with the isolated bacterial inoculum. The artificially inoculated plants were then observed for disease symptom development for a period of 2 weeks.

\section{Inoculation of seeds}

Relatively clean seeds of varieties $\mathrm{V}_{1}$ and $\mathrm{V}_{2}$ were obtained from the Kenya seed company. A $100 \mathrm{ml}$ suspension of the field bacterial isolates (at the concentration of $10^{4} \mathrm{CFU} / \mathrm{ml}$ ) was prepared in $0.85 \%$ saline solution containing $1 \%$ Tween-20 for each experimental variety. About 50 grams of seeds (10 000 seeds) for Copenhagen market variety $\left(\mathrm{V}_{1}\right)$ and another same lot of seeds for Gloria F1 Hybrid $\left(\mathrm{V}_{2}\right)$ were immersed in separate cell suspensions, each of $10^{4} \mathrm{CFU} / \mathrm{ml}$ concentration of the bacterial isolates. The contents were then shaken at 125 r.p.m (revolutions per minute) at a temperature of 27 ${ }^{0} \mathrm{C}$ for 5 minutes. The liquid was removed by a pipette and the seeds spread on a blotting paper to dry overnight in a Bio-Safety cabinet.

\section{Land preparation}

Land for experimental plots was ploughed to a fine tilth and all weeds eliminated. The experimental plots measuring $4 \mathrm{~m} \mathrm{x} 3 \mathrm{~m}$ were demarcated.

\section{Nursery bed and field establishments}

The inoculated seeds were established in separate Greenhouse nursery beds for a period of 3 weeks. Seedlings from the green house were then transplanted into the experimental plots, at spacing of $60 \mathrm{~cm}$ by $60 \mathrm{~cm}$. Diammonium phosphate (DAP) fertilizer was used during transplanting at the rate of one tablespoonful per planting hole. Weeds were controlled through hand weeding and the plants were sprayed with Match 50 EC insecticide to control pests. Top dressing was done when the plants were about $25 \mathrm{~cm}$ in height using one tablespoonful of (Calcium Ammonium Nitrate) CAN fertilizer per plant. The treatments were repeated in 4 replicas and in two different seasons. 


\section{Data collection and analysis}

Disease scoring was done on a scale of 1-9 in accordance with Guo et al., (1991) and Leonel et al., (2015) procedures. This was done to determine the intensity of disease and was achieved through measuring length of the Vshaped lesions developing from the margin of cabbage leaves. The length of V-shaped lesions was measured in centimeters from the leaf margin inwards as described in Table 1. The scoring was done in the field on a weekly basis after crop establishment for a period of 4 weeks in season 1 and 7 weeks in season 2 .

The Zero rating scale was not applied in this research as it referred to situations where rating could not be made. Scale 1 and 2 was applied to plants with minimum symptoms therefore showing the highest level of resistance to black rot disease.

Plants with moderate symptoms scored 3 and 4 implying such plants have moderate resistance to disease. Scale 5, 6 and 7 was reserved for plants with intense symptoms.

The highest scores were 8 and 9 reserved for plants with severe symptoms and even death of plants and such plants showed the highest level of susceptibility to black rot disease.

\section{Results and Discussion}

Isolation of Xanthomonas campestris pv. Campestris

Pale yellowish and convex mucoid bacterial colonies were observed in the laboratory plates (Plate 1).

Plate 1 above shows the yellowish, convex mucoid bacterial colonies obtained in the laboratory during isolation of Xanthomonas campestris pv. Campestris.

\section{Identification of Xanthomonas campestris pv. Campestris}

The field bacterial isolates stained red in colour upon staining with crystal violet and counter-staining with Methyl red stains, which is characteristic to Xanthomonas campestris $p v$. Campestris, being a gram negative bacterium. Plate 2 shows the results of the pathogenicity tests carried out to confirm the identity of Xanthomonas campestris $p v$. Campestris field isolates from the laboratory.

The V-shaped lesions developed from the leaf margins after carrying out pathogenicity tests are characteristic symptoms of the bacterium Xanthomonas campestris pv. Campestris that causes black rot diseases. One month old seedlings of cabbage were sprayed with $10^{4}$ $\mathrm{CFU} / \mathrm{ml}$ bacterial suspensions and the $\mathrm{V}$ shaped lesions were seen developing from the leaf margin after 10 days of inoculation.

\section{Varietal resistance to black rot disease}

To achieve this objective of this research, a total of 6 observations were made; Disease mean score for season 1, Disease mean score for season 2, Variety diseases mean score for season 1, Variety diseases mean score for season 2, Variety diseases mean score across seasons and disease mean score across seasons 1 and 2 as shown in Table 2 to 4 respectively.

Means figures in the column with different letters are significantly different $(\mathrm{p}<0.05)$. The scores were significantly different at different times, highest (4.359) at time 7 and lowest (1.750) in season two. In season 1, the trend was similar to season 2. These results therefore indicate that disease increased with increase in time during the plant growth.

Means figures in the column with different letters are significantly different $(\mathrm{p}<0.05)$. The 
results indicate that there is evidence of significant differences in disease score between the two varieties in seasons 1 and 2, and across the seasons. There were significantly $(\mathrm{p}<0.05)$ high scores for disease (3.506) for variety 1 compared to variety 2 (2.733) across the seasons.

Means figures in the column with different letters are significantly different $(\mathrm{p}<0.05)$ where $S_{1}$ is season 1 and $S_{2}$ is season 2 . The result indicates that there is evidence of significant differences in disease score between the two seasons. The score were significantly $(\mathrm{p}<0.05)$ higher in season 2 (3.228) compared to season 1 (2.930). Plate 3 shows results from varieties 1 and 2 plants germinated from seeds inoculated with field bacterial isolates at a concentration of $10^{4}$ $\mathrm{CFU} / \mathrm{ml}$ (Colony Forming Units) suspensions of Xanthomonas campestris pv. Campestris.

Table.1 Disease score rates

\begin{tabular}{|c|c|}
\hline Length of V-Shaped Lesion & Score Rates \\
\hline$<0.5 \mathrm{~cm}$ & 1 \\
\hline$>0.5-1.0 \mathrm{~cm}$ & 2 \\
\hline$>1.0-1.5 \mathrm{~cm}$ & 3 \\
\hline$>1.5-2.0 \mathrm{~cm}$ & 4 \\
\hline$>2.0-3.0 \mathrm{~cm}$ & 5 \\
\hline$>3.0-4.0 \mathrm{~cm}$ & 6 \\
\hline$>4.0-5.0 \mathrm{~cm}$ & 7 \\
\hline$>5.0-6.0 \mathrm{~cm}$ & 8 \\
\hline$>6.0$ cm to plant death & 9 \\
\hline Where "<" Imply lesions measuring less than while “>” means lesions measuring more than
\end{tabular}

Table.2 Disease mean score across seasons

\begin{tabular}{|l|l|l|}
\hline $\begin{array}{l}\text { Time in Weeks after crop } \\
\text { establishment }\end{array}$ & \multicolumn{1}{|c|}{ Season 1 } & \multicolumn{1}{c|}{ Season 2 } \\
\hline 7 & & $4.359 \mathrm{a}$ \\
\hline 6 & & $4.125 \mathrm{~b}$ \\
\hline 5 & & $3.594 \mathrm{c}$ \\
\hline 4 & $4.156 \mathrm{a}$ & $3.281 \mathrm{~d}$ \\
\hline 3 & $3.907 \mathrm{~b}$ & $2.984 \mathrm{e}$ \\
\hline 2 & $2.297 \mathrm{c}$ & $2.500 \mathrm{f}$ \\
\hline 1 & $1.359 \mathrm{~d}$ & $1.750 \mathrm{~g}$ \\
\hline S.E & 0.19998 & 0.1898 \\
\hline CV \% & 54.60 & 47.04 \\
\hline P-value & $<0.0001$ & $<0.0001$ \\
\hline & & \\
\hline
\end{tabular}


Table.3 Disease mean score for varieties

\begin{tabular}{|l|l|l|l|}
\hline Variety & Season 1 & Season 2 & Across Seasons \\
\hline $\mathrm{V}_{1}$ & $3.242 \mathrm{a}$ & $3.656 \mathrm{a}$ & $3.506 \mathrm{a}$ \\
\hline $\mathrm{V}_{2}$ & $2.617 \mathrm{~b}$ & $2.799 \mathrm{~b}$ & $2.733 \mathrm{~b}$ \\
\hline Mean & 2.930 & 3.228 & 3.119 \\
\hline SE & 0.1414 & 0.1015 & \\
\hline CV \% & 54 & 47 & 51 \\
\hline P-value & $<0.0020$ & $<0.0001$ & $<0.0001$ \\
\hline
\end{tabular}

Table.4 Disease mean score for seasons 1 and 2

\begin{tabular}{|l|l|}
\hline Season & Disease mean scores \\
\hline $\mathbf{S}_{\mathbf{2}}$ & $3.228 \mathrm{a}$ \\
\hline $\mathbf{S}_{\mathbf{1}}$ & $2.930 \mathrm{~b}$ \\
\hline S.E \pm & 0.075 \\
\hline CV \% & 50.58 \\
\hline P-value & $<0.0001$ \\
\hline
\end{tabular}

Plate.1 Cultures of Xanthomonas campestris pv. campestris colonies

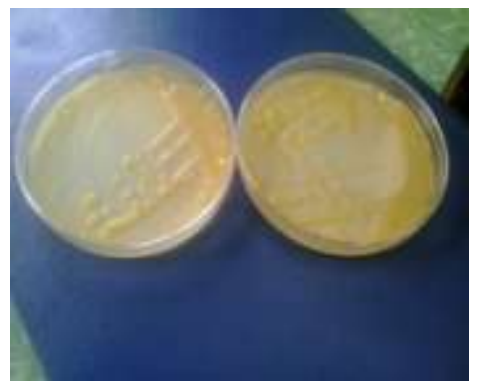

Plate.2 Results of pathogenicity test after inoculating young seedlings of cabbage with isolates of Xanthomonas campestris pv. Campestris

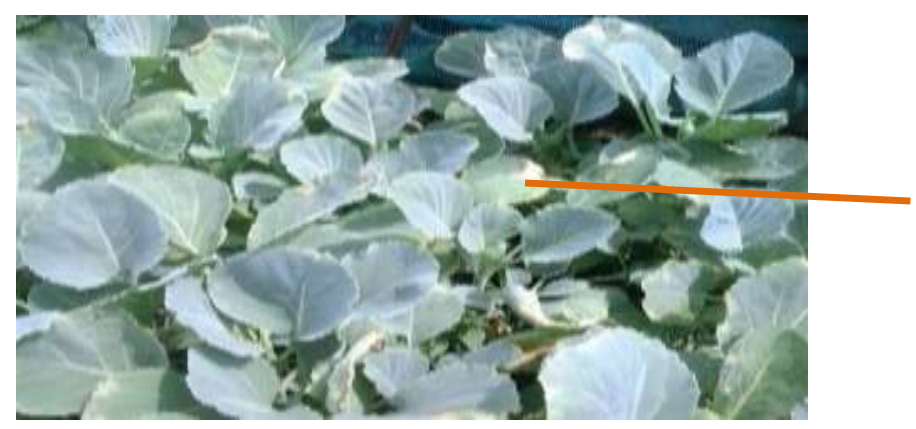

V-shaped lesion 
Plate.3 (a) Variety 1 plants from seeds inoculated with isolates of Xanthomonas campestris pv. Campestris (b) Variety 2 plants from seeds inoculated with isolates of Xanthomonas campestris pv. Campestris

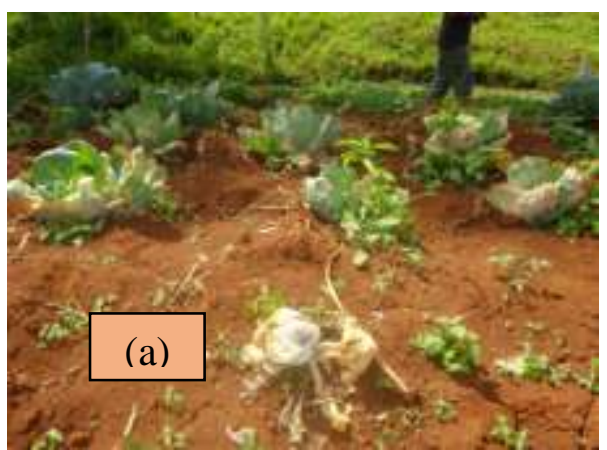

The results obtained in the laboratory experiments showed the yellowish, convex mucoid bacterial colonies that are characteristic to Xanthomonas campestris $p v$. Campestris (Plate 1). This coupled with the staining characteristics and the pathogenicity tests carried out (Plate 2) clearly confirm the identity of the bacterium Xanthomonas campestris pv. Campestris.

The results indicate that there is evidence of significant difference in disease score between the two varieties and across the two seasons. There were significantly $(p<0.05)$ high scores (3.506) for variety 1 compared to variety 2 (2.733) across seasons (Table 3). The results also show that variety 1 had higher disease scores as compared to variety 2 in both seasons 1 and 2 . These results therefore clearly show that Gloria F1 hybrid germplasm (variety 2) is more resistant to black rot disease as compared to Copenhagen market germplasm (variety 1). On the basis of these findings, Copenhagen market germplasm can therefore be described as being more susceptible to black rot disease. Similarly as shown in Table 4, there were significantly $(\mathrm{p}<0.05)$ higher scores in season 2 (3.228) compared to season 1 (2.930). From the results, it can be concluded that black rot disease was more severe in season 2 as compared to season 1 . The bacterium

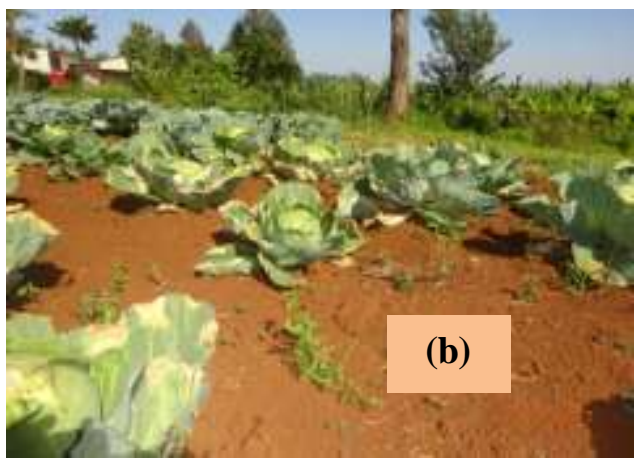

Xanthomonas campestris pv. Campestris, which is the pathogen that causes black rot disease of cabbage, thrives well in warm and wet weather conditions that are characteristic of the second planting season in Kisii County. The County has two planting seasons with different weather conditions. The first planting seasons which is characterized by long rains and cold weather conditions ranges from the month March to August while the second planting season which has short rains with warm temperatures, ranges from the months of September to December. Wet and warm conditions favoured the survival and quick spread of the bacteria.

This therefore explains why disease score in the second season was higher as compared to the first planting season. Massomo (2003) argues that heavy losses with poor quality cabbage heads in occur in growing seasons with heavy rains and warm weather conditions which conform to these results. There scores were significantly different at different times, with highest (4.359) at time 7 and lowest (1.750) at time 1 (the initial stages of crop development) for season 2 (Table 2). A Similar trend was observed in season 1 as evidenced by the same Table 2. This result illustrates that it required adequate time, favorable conditions and a susceptible host for the virulent pathogen to cause disease. 
The pathogen population increased with time thus colonizing the plant tissues system and hence causing severe disease as the plants continued growing. Disease was less severe at the earlier stages of crop development due to low pathogen population.

Plate 3 (a) shows that the intensity of black rot disease in Variety 1 (Copenhagen market variety) was higher as compared to variety 2 (Gloria Hybrid) which is shown in Plate 3 (b). As it can be observed in Plate 3 (a) and Plate 3 (b), the number of plants in variety 2 which survived the disease to harvesting age was higher as compared to that in variety 1 . Specifically, Plate 3 (a) shows more gaps as results of plant death caused by black rot disease. Once again, this implies that Gloria F1 hybrid germplasm is more resistant to black rot disease as compared to Copenhagen market variety. It can therefore be deduced that Copenhagen market variety is a susceptible variety to black rot disease.

In conclusion this research study sought to evaluate and identify the black rot diseaseresistant germplasm among the common cabbage varieties grown by farmers in Kisii County. This was in realization of the fact that black rot disease, caused by Xanthomonas campestris $p v$. campestris, is the major cause of losses in cabbage production by small scale farmers.

The results obtained indicate that there is evidence of significant difference in disease score between the two varieties studies in this research and across the two seasons. There were significantly $(\mathrm{p}<0.05)$ high scores for variety 1 compared to variety 2 throughout seasons 1 and 2 , and across the seasons. It was also noted that season 2 had significantly $(\mathrm{p}<0.05)$ high disease score as compared to season 1.

Therefore, these research findings indicate that Gloria F1 hybrid germplasm is more resistant to black rot disease as compared to Copenhagen market variety, which can be describe as being more susceptible to black rot disease. It can thus be concluded that resistant varieties can be used together with seasons that do not favour disease development as one way of managing black rot disease in cabbage crop farms for higher yields.

\section{Recommendation}

The findings of this study indicate that Gloria hybrid variety is more resistant to black rot disease as compared to Copenhagen Market variety. The research results also showed that the disease was more severe in season 2 as compared to season 1. It was therefore, recommended that farmers consider planting cabbage varieties that are more tolerant to black rot disease in seasons when the disease is less severe, as the best practices for managing black rot disease in cabbage farms in Kisii County.

\section{Acknowledgement}

We wish to acknowledge the Kenya Agricultural and Livestock Research Organization center- Kisii branch for allowing us to use their land and laboratory for this research.

\section{References}

Alana, R., Viliam, Z. (2008). Vegetable Crops Production Guide for Nova Scotia. Agra point.

Alvarez, A. M. (2000). Black rot of crucifers. In: Slusarenko, A. J; Fraser, R. S. S; van, L. L. C (Eds.) Mechanisms of Resistance to Plant Diseases. Dordrecht, The Netherlands: Kluwer Academic Publishers. Pg 21-52.

Arthur, G. C. (2012). Colewort and Cole crops. University of California.

Bila, J. (2008). Status of Bacterial Black rot 
of Brassicas in Southern Region of Mozambique: Survey, Detection and Identification of the Causal Agent Xanthomonas campestris $p v$. campestris. M.Sc. thesis, University of Copenhagen, Denmark. pg102.

Bila, J., Mortensen, C. N., Andresen, M., Vicente, J. G., Wulff, E. G. (2013). Xanthomonas campestris pv. campestris Race 1 is the main causal agent of Black rot of Brassicas in Southern Mozambique. University of Copenhagen, Denmark. African Journal of Biotechnology Vol 12 (26): 602-610.

Bong, Y.-S., W.-J.Shin, M.K. Gautam, Y.J.Jeong, A.-R.Lee, C.-S.Jang, Y.P.Lim, G.-S.Chung, and K.-S. Lee, 2012: Determining the geographical origin of Chinese cabbages using multi-element composition and strontium isotope ratio analyses. Food Chem. 135, 2666-2674.

Fahey, J. W., Zalemann, A. T., Talalay, P. (2001). The chemical diversity and distribution of glucosinolates and isothiocyanates among plants. Phytochemistry, 56, pg 5-51.

Guo, H., Dickson, M. H., Hunter, J. E. (1991). Brassica napus sources of Resistance to Black Rot in crucifers and inheritance of resistance. New York State of Agricultural Experiment station. Cornell University, Geneva, NY 14456-0462.Hort Science Journal Vol. 26 (12) 1547.1991.

Hall, J. C., Sytsma, K. J., Iltis, H. H. (2002). Phylogeny of Capparaceae and Brassicaceae based on chloroplast sequence data. American Journal of Botany 89 (11): 1826-42.

Kim, J., Y. Jung, B. Song, Y.-S.Bong, D.H. Ryu, K.-S.Lee, and G.-S. Hwang, 2013: Discrimination of cabbage (Brassica rapa ssp. pekinensis) cultivars grown in different geographical areas using H-NMRbased metabolomics. Food Chem. 137, 68-75.

Lee J, Izzah N. K, Jayakodi M, Perumal S, Joh H. J, Lee H. J, et al., (2015). Genome-wide SNP identification and QTL mapping for black rot resistance in cabbage. BMC Plant Biol. 15: 32.

Lema, M., P. Soengas, P. Velasco, P. Francisco, and M. E. Cartea.(2011). Identification of sources of resistance to Xanthomonas campestris pv. campestris in Brassica napus crops. Plant Dis. 95, 292-297.

Lema M, Cartea M. E, Sotelo T, Velasco P, Soengas P. (2012). Discrimination of Xanthomonas campestris pv. campestris races among strains from northwestern Spain by Brassica spp. genotypes and rep-PCR. Eur. J. Plant. Pathol.133: 159-169.

Leonel, A. A. (2015). Evaluation of resistance on Cabbage varieties: Resistance against Xanthomonas campestris pv. campestris in Mozambique. College of Agronomy and forest Engineering, Zambezi university. International Journal of Agriculture and Crop Sciences. Vol. 8 (5) 723-731. 2015.

Lo, C. T., Wang, K. M. (2001). Inoculum sources of Black Rot of Wasabi, caused by Phoma wasabiae. Plant Pathol Bull. 10: 88-92.

Massomo, S.M.S., 2002. Black rot of cabbage in Tanzania: Characterization of Xanthomonas campestris pv. campestris and disease management strategies. Ph.D. Thesis. The Royal Veterinary and Agricultural University, Copenhagen, Denmark, p. 215.

Massomo, S. M. S., Mabagala, R. B., Swai, I. S., Hockenhull, J., Mortensen, C. N. (2003). Evaluation of varietal resistance in cabbage against the black rot pathogen, Xanthomonas 
campestris pv. campestris in Tanzania. Crop Protection 23 (4): 315-325.

Mike, A. (2009). Natural Health News \& Self- Reliance.

Miller, S. A., Lewis, I. M. L. (2005). Hot water treatment of vegetable seeds to eradicate bacterial plant pathogens in organic production systems. Plant Pathology Extension Fact sheet HYG3086-05. The Ohio State University.

Otipa M, Kamau R, Gekone M. (2013). Pest management decision guide: Green and yellow list. Black rot diseasePlantwise. East African pest management innovation lab. The Ohio State University, College of food, Agriculture and Environmental Sciences

Preedy, R. V., Vatson, R. R., Patel, B. V. (2011). Nuts and Seeds in health and disease prevention. Academic press Publications of Elsevier, 32 Jamestown Road, London NW1 7BY, UK.

Singh, D., Dhar, S., and Yadava, D. K. (2011). Genetic and pathogenic variability of Indian strains of Xanthomonas campestris pv. campestris causing black rot disease in crucifers. Curr.Microbiol.63, 551-560. doi: 10.1007/s00284-011-0024-0.

Varela A. M, Seif A. A and Lohr B. (2003). A guide to Integrated Pest Management in Brassicas production in Eastern and Southern Africa. ICIPE, Nairobi Kenya. ISBN: 9290641487.

Vicente, J. G., Conway, J., Roberts, S. J., Taylor, J.D. (2001). Identification and origin of Xanthomonas campestris pv. campestris races and related pathovars. Phytopathology 91: 492499.

Vicente, J. G. and E. B. Holub. (2013). Xanthomonas campestris pv. campestris (cause of black rot of crucifers) in the genomic era is still a worldwide threat to Brassica crops. Mol. Plant Pathol.14, 2-18.

Williams, P. H., 2007: Black rot. In: S. R. Rimmer, V. I. Shattuck, and L. Buchwaldt (eds), Compendium of Brassica Diseases, 60-62, American Phytopathological Society, St. Paul.

Zhao, J., X. Wang, B. Deng, P. Lou, J. Wu, R. Sun, Z. Xu, J. Vromas, M. Koorneef and G. Bonnema, 2005: Genetic relationships within Brassica rapa as inferred from AFLP fingerprints. Theor. Appl. Genet. 110, 1301-1314.

\section{How to cite this article:}

Jackson Ombuna Gitange, Johnson Nyangeri and Samson Maobe. 2019. Managing Black Rot Disease of Cabbage by Use of Tolerant Varieties within Kisii County- Kenya. Int.J.Curr.Microbiol.App.Sci. 8(01): 912-921. doi: https://doi.org/10.20546/ijcmas.2019.801.099 